\title{
CHARACTERISTICS OF THE BIOGAS INDUSTRY OF LATVIA
}

\author{
Janis MILLERS, Latvia University of Life Sciences and Technologies, 2 Liela Street, Jelgava, LV-3001, Latvia, \\ janismillers99@gmail.com (corresponding author) \\ Irina PILVERE, Latvia University of Life Sciences and Technologies, 2 Liela Street, Jelgava, LV-3001, Latvia, irina.pilvere@ 1lu.lv
}

\begin{abstract}
Biomass and biowaste could be processed into biogas, which, in turn, could be used to generate electrical and thermal energy. Agriculture, especially livestock farming, has significant potential for bioenergy production, mainly due to its relatively low cost. In 2020, 52 biogas plants operated in Latvia, which sold the produced electrical energy under the mandatory procurement scheme (MP). The biogas plants consumed inputs from agriculture, landfills and water treatment facilities. The use of biogas for energy production should be encouraged, as the inputs - waste -, which the biogas is produced from, are used efficiently. By supporting waste processing and energy production in Latvia, the country's independence from fossil energy sources could be increased, as well as the proportion of renewable energy sources in final energy consumption would increase by $50-70 \%$ by 2030 compared with 1990 . Accordingly, the present research aims to analyse the performance of the biogas industry of Latvia. The research concluded that since 2017 when the largest output of electricity was reported in Latvia (7.35 TWh (Terawatt hours)), the output has continued decreasing every year, including the electricity produced from renewable sources and by biogas plants. In the period 2016-2020 in Latvia, the average proportion of electricity produced by biogas plants in the total electricity output was $5.36 \%$. In 2021, 46 biogas plants sold electricity under the mandatory procurement scheme, which was 6 plants fewer than in 2020; therefore, this proportion decreased to $3.63 \%$. The performance of biogas plants in the first half of 2021 was lower and significantly lagged behind that in 2020, which was a result of significant amendments made to the legal framework at the end of 2020 regarding the efficiency of cogeneration plants. Consequently, the biogas plants diversified their operations or stopped production, and it could be expected that in 2021 the amount of electricity sold under the mandatory procurement scheme would decrease by at least $20 \%$.
\end{abstract}

Keywords: biogas, agricultural waste, bioenergy production

\section{INTRODUCTION}

The proportion of renewable sources in total electricity output in Europe is low, yet the European Union's (EU) long-term energy policy aims to reduce energy consumption from fossil fuels and promote energy production from renewable sources. Electricity from biogas, solar, hydro and wind energy are the dominant kinds of renewable electricity, which will reduce the country's dependence on energy imports, increase energy supply security and reduce air pollution. (Latvian bioeconomy..., 2017) The EU policy envisages a transition to a carbon-neutral economy by 2050 (Climate neutral 2050...,2019). The EU's Green Deal envisages reducing GHG emissions by at least $50 \%$ by 2030 compared with 1990. Achieving this target requires further decarbonisation of the energy system (Green Deal..., 2019) $\left.\mathrm{Methane}_{(\mathrm{CH}}\right)$ is the second largest anthropogenic greenhouse gas (GHG) after carbon dioxide $\left(\mathrm{CO}_{2}\right)$. Methane is a significant contributor to global warming because its heat absorption capacity is 32 times higher than that of $\mathrm{CO}_{2}$ over a 100 -year period. (Semra Bakkaloglu et al., 2021)

Reducing carbon emissions from the economy is possible if introducing high-quality and cost-effective, lowcarbon technological solutions available in the global market. A widely accepted GHG-reducing technological solution is the production of biogas from waste, which is a renewable energy source.

The market trend shows that the European biogas industry is shifting from a pattern that is still dominated by energy crops and electricity generation through cogeneration to a pattern dominated by organic waste and agricultural byproducts used as inputs, in which biogas is converted into biomethane for various applications (transport, chemical production, thermal energy etc.). (Ulysse Brémond et al., 2020) Biogas output in Europe doubled from 2008 to $2016-$ from 93 to 187 TWh. In 2018, the International Energy Agency (IEA) reported that biogas and biomethane output in 2018 could meet almost $20 \%$ of global gas demand (International Energy..., 2020).

The production of biogas from agricultural waste as well as biogas from water treatment facilities and landfills, make a positive impact on the environment, thereby reducing GHG emissions. Methane produced in biogas fermenters is burned for renewable energy production, emitting less carbon dioxide than if burning fossil fuels. (Robert Czubaszek et al., 2020). The rate of GHG reduction varies depending on the kind of energy source being replaced by biogas. Biogas production should be regarded as an opportunity for the agricultural industry. The supply of inputs is a potentially new

Copyright (C) 2021 The Authors. Published by Vytautas Magnus University. This is an open-access article distributed under the terms of the Creative Commons Attribution License (CC BY 4.0), which permits unrestricted use, distribution, and reproduction in any medium, provided the original author and source are credited. 
source of income, while the processing of manure and slurry through anaerobic fermentation represents an alternative leading to lower costs, as chemical fertilizers are less consumed. (Tong Zhu et al., 2019)

Today, energy has become one of the most important contributors to economic competitiveness and independence. Latvia is rich in renewable energy sources that are not used enough for energy production. The use of domestic energy sources for energy production need to be encouraged. (Cross-Sectoral..., 2014) The National Development Plan of Latvia for 2021-2027 prescribes that the GHG emissions produced need to be offset by carbon sequestration or, by using specific technologies, the GHG emissions are not released. (Cross-Sectoral..., 2020), (M.Gustafsson et al., 2021) In 2020 in Latvia, 1.25 TWh of energy was produced by renewable energy facilities, which accounted for $22.8 \%$ of the total electricity output. The proportion of electricity from biogas cogeneration was $5.6 \%$ of the total or $0.30 \mathrm{TWh}$ of electricity. (JSC "High Voltage..., 2020)

Accordingly, the present research aims to analyse the performance of the biogas industry of Latvia. The research put forward a hypothesis: the amount of electrical energy generated by biogas cogeneration plants tends to decrease in Latvia. To achieve the research aim, two specific tasks were set: 1) to analyse the total output of electrical energy and identify the proportions of electrical energy from renewable sources and biogas plants; 2) examine the performance of biogas plants by using publicly available information sources.

\section{RESEARCH METHODS}

The research employed general and structural research methods. The descriptive, analysis and synthesis methods were used to formulate research results. The research made calculations using secondary data, which were available in public reports provided by public administration institutions. Information on the number of biogas plants and their distribution by origin of inputs was obtained from the Ministry of Economics of the Republic of Latvia (Ministry of Economics..., 2021), on the installed electric capacities of agricultural biogas plants - from the State Construction Control Bureau of Latvia (State Construction..., 2021) and on electricity output - from the JSC "High Voltage Network". The data were used to identify the capacity distribution of biogas plants and the proportion of electricity generated by biogas plants in the total output of renewable energy. The data on installed electric capacity and the number of biogas plants are given for 2020 and the first half of 2020.

\section{RESEARCH RESULTS AND DISCUSSION}

\section{OUTPUT OF ELECTRICAL ENERGY AND THE DISTRIBUTION BY SOURCE IN LATVIA}

Since 2008, the biogas and renewable energy industry in Latvia tended to expand overall, as EU funding has been allocated for the construction of facilities and public procurement of subsidized electricity (mandatory procurement scheme) has been introduced. Therefore, it is necessary to identify changes in the output of electricity from renewable sources and biogas in Latvia over the last five years (2016-2020) (Figure 1).

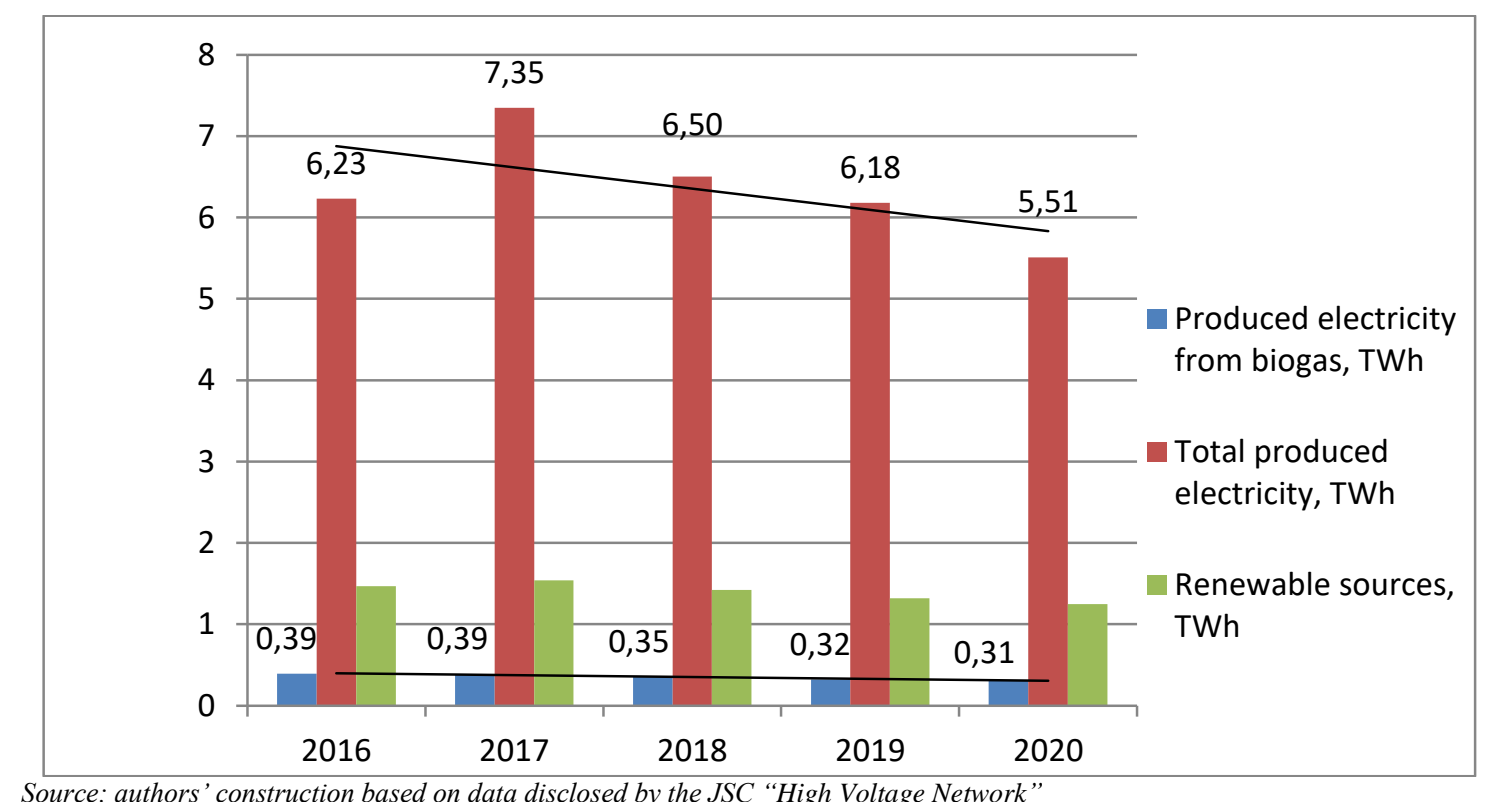

Figure 1. Total output of electricity, the output of electricity from renewable sources and generated by biogas plants in Latvia in 2016-2020, TWh (JSC “High Voltage..., 2020)

Since 2017 when the largest output of electricity was reported in Latvia (7.35 TWh), the output has continued decreasing every year. Over the five-year period analysed, a decrease in the total output of electricity from the base year was $11.2 \%$ or $0.72 \mathrm{TWh}$, while a decrease in 2020 compared with 2017 was $25 \%$ or $1.84 \mathrm{TWh}$. In the period 2016-2020, 
the total output of electricity from renewable sources decreased by $15 \%$ or $0.22 \mathrm{TWh}$, while a decrease in the output of electricity produced by biogas plants was $20.5 \%$ or $0.08 \mathrm{TWh}$, which was 5 percentage points more than that for the total output of electricity from renewable energy sources. From 2016 to 2020, the average proportion of electricity from biogas in the total output of electricity was $5.36 \%$, ranging from $6.26 \%$ in 2016 to $5.18 \%$ in 2019 , while the total output of electricity from renewable energy sources varied from $20.95 \%$ in 2017 to $23.60 \%$ in 2016.

According to the data on electricity generation in 2020, the net consumption of electricity in Latvia was 7.13 TWh, and the average electricity price at a power exchange decreased to $34.05 \mathrm{EUR}_{\mathrm{MWh}}{ }^{-1}$. (Enefit..., 2020) This means that in 2020, the demand for electricity in Latvia was met by domestic electricity generation sources to the extent of $77 \%$, which, compared with 2019, was a decrease of $7.5 \%$.

In Latvia in 2020, the total installed capacity of facilities running on renewable energy sources - hydro power plants, biomass, biogas and wind facilities - was 287.69 MW. In Latvia, biogas cogeneration plants generated 59.75 MW of electricity under the mandatory procurement scheme or almost $21 \%$ of the total output of renewable electricity (biogas, biomass, natural gas cogeneration, hydro, solar and wind power plants) in terms of installed capacity. (Ministry of Economics..., 2021)

\section{PERFORMANCE OF BIOGAS PLANTS IN LATVIA}

In 2021, 46 biogas plants generated and sold electricity under the mandatory procurement scheme. Of them, 36 or $78 \%$ were agricultural biogas plants with a total capacity of $39.67 \mathrm{MW}$ or $73 \%$ of the total capacity of biogas plants (with an average capacity of $1.10 \mathrm{MW}$ ), 5 or $11 \%$ were those located at municipal landfills, with a total capacity of $8.80 \mathrm{MW}$ or $17 \%$ of the total (with an average capacity of $1.76 \mathrm{MW}$ ), 5 or $11 \%$ produced biogas from food waste, and their capacity was $5.33 \mathrm{MW}$ or $10 \%$ of the total (with an average capacity of $1.07 \mathrm{MW}$ ). In 2021 in Latvia, three biogas plants with a total capacity of $3 \mathrm{MW}$ did not sell their electricity under the mandatory procurement scheme, and the plants sold electricity at the power exchange price or used it for own consumption. A significant decrease in the number of biogas plants (by 6) in Latvia occurred in 2021.

The performance of biogas plants in 2020 is summarized in Table 1, which is publicly available on the website of the national biogas cogeneration plant supervisory institution State Construction Control Bureau. In Latvia in 2020, most biogas plants -26 or $50 \%$ - had a capacity of $0.5-1.0 \mathrm{MW}, 11$ or $21 \%$ had a capacity of $1.5-2.0 \mathrm{MW}$, 7 were small with a capacity of up to $0.5 \mathrm{MW}$. This means that most biogas plants were medium-sized with a capacity of 0.5-1 MW. One of the biogas plants could be classified as a micro-biogas plant, as its capacity was $0.16 \mathrm{MW}$.

Table 1. Performance of biogas plants in Latvia by installed capacity in 2020

\begin{tabular}{|c|c|c|c|c|c|c|c|c|c|c|c|c|}
\hline \multirow[t]{2}{*}{$\begin{array}{c}\text { Installed } \\
\text { capacity, } \\
\text { MW }\end{array}$} & \multicolumn{2}{|c|}{ Biogas plants } & \multicolumn{3}{|c|}{$\begin{array}{l}\text { Purchased under MP } \\
\text { scheme, GWh* }\end{array}$} & \multicolumn{3}{|c|}{$\begin{array}{c}\text { Purchased under MP } \\
\text { scheme, VAT excluded, } \\
\text { mln. EUR }\end{array}$} & \multirow{2}{*}{$\begin{array}{l}\text { Avg. } \\
\text { price } \\
\text { EUR } \\
\mathrm{kWh}^{-1 *}\end{array}$} & \multicolumn{3}{|c|}{$\begin{array}{c}\text { Support above market price, } \\
\text { mln. EUR }\end{array}$} \\
\hline & Number & $\begin{array}{l}\% \text { of } \\
\text { total }\end{array}$ & Total & $\begin{array}{l}\% \text { of } \\
\text { total }\end{array}$ & $\begin{array}{c}\text { Avg. per } \\
\text { plant }\end{array}$ & Total & $\begin{array}{l}\% \text { of } \\
\text { total }\end{array}$ & $\begin{array}{l}\text { Avg. per } \\
\text { plant }\end{array}$ & & Total & $\begin{array}{l}\% \text { of } \\
\text { total }\end{array}$ & $\begin{array}{l}\text { Avg. per } \\
\text { plant }\end{array}$ \\
\hline$<0.5$ & 7 & 13.5 & 8.83 & 2.9 & 1.26 & 1.52 & 2.9 & 0.21 & 0.18 & 1.22 & 2.9 & 0.17 \\
\hline $0.5-1.0$ & 26 & 50.0 & 122.48 & 40.1 & 4.71 & 22.62 & 42.8 & 0.87 & 0.17 & 18.31 & 43.7 & 0.70 \\
\hline $1.0-1.5$ & 6 & 11.5 & 29.05 & 9.5 & 4.84 & 4.95 & 9.4 & 0.82 & 0.16 & 3.45 & 8.2 & 0.57 \\
\hline $1.5-2.0$ & 11 & 21.2 & 114.32 & 37.4 & 10.39 & 19.80 & 37.5 & 1.80 & 0.17 & 15.95 & 38.1 & 1.45 \\
\hline $2.0-6.5$ & 2 & 3.8 & 30.93 & 10.1 & 15.46 & 3.98 & 7.4 & 1.99 & 0.14 & 2.97 & 7.1 & 1.48 \\
\hline Total & 52 & 100.0 & 305.61 & 100.0 & 5.87 & 52.87 & 100.0 & 1.02 & 0.17 & 41.90 & 100.0 & 0.81 \\
\hline
\end{tabular}

*1 GWh = 1000 kilowatt hours $(\mathrm{kWh})$

Source: authors' calculations based on the Ministry of Economics, 2021

The capacity of 17 biogas plants was 1-2 MW, most of the plants ran on inputs of agricultural origin. In Latvia, only one biogas plant had a capacity of $6.5 \mathrm{MW}$, and it was located at a landfill. There were some other companies operating in Latvia that were not classified as biogas plants, yet they produced biogas and used it for their own needs, e.g. "Cesu beer" Ltd. (Cesu beer..., 2020) The number of micro-biogas plants should increase in the future, especially on livestock farms and at food companies, which would use the electrical and thermal energy generated for own consumption.

In 2020, the total amount of electricity sold by biogas plants under the MP scheme was $305.61 \mathrm{GWh}$, of which $40 \%$ by plants with a capacity of $0.5-1.0 \mathrm{MW}, 37 \%$ by plants with a capacity of $1.5-2.0 \mathrm{MW}$, and $10 \%$ by plants with a capacity of 2.0-6.5 MW. The average amount of electricity sold by a biogas plant ranged from 1.26 GWh for small ones to $15.46 \mathrm{GWh}$ for large ones, or on average $5.87 \mathrm{GWh}$.

The total amount of electricity purchased from biogas plants was EUR $52.87 \mathrm{mln}$., of which support above the market price amounted to EUR $41.90 \mathrm{mln}$. or $79 \%$. The electricity price under the mandatory procurement scheme for the producers of electricity from biogas varied from $0.14 \mathrm{EUR} \mathrm{kWh}^{-1}$ for large biogas plants to $0.18 \mathrm{EUR}_{\mathrm{kWh}} \mathrm{k}^{-1}$ for small ones. Due to the difference in price per $\mathrm{kWh}$, the difference between the total sum spent on electricity and the amount of support became slightly smaller. Of the total sum, $43 \%$ was received by 26 biogas plants with a capacity of $0.5-1.0 \mathrm{MWe}$, $37 \%$ was received by 11 biogas plants with a capacity of 1.5-2.0 MWe; therefore, the support above the market price was $44 \%$ and $38 \%$ of the total, respectively.

In Latvia, the operation of biogas plants is governed by a changing and complex legal framework. In 2020 in Latvia, 32 out of 52 biogas cogeneration plants operated in accordance with Cabinet Regulation No. 560 of 2 September 2020 "Regulations regarding Electricity Generation from Renewable Energy Sources as well as Price Setting Procedures and Supervision", whereas 20 plants operated in accordance with Cabinet Regulation No. 561 "Regulations regarding 
Electricity Generation in Cogeneration Mode, Supervision and Price Setting”. The main differences between the two Cabinet regulations (No. 561 and No. 560) lie in the historical goals of the Cabinet regulations replaced by these documents. Both Cabinet regulations are basically similar, yet the earlier Cabinet regulation stipulates that biogas plants that previously operated in accordance with the Cabinet regulation No. 221 (2010) must use thermal energy efficiently from the very beginning of the plant's operation. The efficient use of thermal energy generated by biogas plants in cogeneration mode, which previously operated in accordance with Cabinet Regulation 262 (2010), was not a priority, and emphasis was placed on electricity generation.

When adopting the Electricity Market Law of the Republic of Latvia (2005), the legislator envisaged that in order to efficiently produce thermal energy in cogeneration mode, Section 28 of the Electricity Market Law "Electricity Generation in the Cogeneration Plant" would be supplemented based on Directive 2004/8/EC of the European Parliament and of the Council of 11 February 2004 on the promotion of cogeneration based on a useful heat demand in the internal energy market and amending Directive 92/42/EEC. Based on this section, Cabinet Regulation No. 921 "Regulations regarding Electricity Generation in Cogeneration Mode" was adopted in 2006, which in 2010 was replaced by Cabinet Regulation No. 221 and in 2020 by Cabinet Regulation No. 561 "Regulations regarding Electricity Generation in Cogeneration Mode, Supervision and Price Setting".

To foster the output of electricity from renewable energy sources and in turn meet some part of the total demand for electricity by all end-users in Latvia, Section 29 of the Electricity Market Law "Generation of Electricity by Using Renewable Energy Sources" was amended based on Directive 2001/77/EC of the European Parliament and of the Council of 27 September 2001 on the promotion of electricity produced from renewable energy sources in the internal electricity market. Based on Section 29 of the law, Cabinet Regulation No. 503 of 24 July 2007 "Regulations regarding Electricity Generation by Using Renewable Energy Sources" was passed, which was replaced by Cabinet Regulation No. 198 of 24 February 2009 "Regulations regarding Electricity Generation by Using Renewable Energy Sources and Price Setting Procedures", followed by Cabinet Regulation No. 262 of 16 March 2010 "Regulations regarding Electricity Generation by Using Renewable Energy Sources and Price Setting Procedures" and Cabinet Regulation No. 560 of 2 September 2020 "Regulations regarding Electricity Generation from Renewable Energy Sources as well as Price Setting Procedures and Supervision". The Cabinet regulations changed relatively frequently and created instability for entrepreneurs engaged in the biogas industry, who needed to adapt to the new regulations. The national government sought to introduce increasingly complex and unfavourable MP conditions for the entrepreneurs. Undoubtedly, biogas cogeneration plants need to be highly efficient (efficient use of thermal and electrical energy). However, the changing legal framework governing the operation of cogeneration plants created uncertainty and jeopardized the long-term viability of the industry.

The current Cabinet regulations (No. 561 and No. 560) require that biogas cogeneration plants need to meet the high-efficiency cogeneration criterion - use at least $75 \%$ of the thermal energy produced. This restricts their operation, as initially there were no such rules when the biogas plants were built, and the plants are forced to introduce various technological innovations and adapt to the situation or to stop operating if it is not possible to meet the requirements set by the changing legal framework. In addition, the operation of biogas plants is regularly inspected by various national supervisory authorities.

It is important to analyse the efficiency and loads of biogas cogeneration plants operating under the mandatory procurement scheme (Table 2). Only 14 out of 49 plants (28.6\% of the total) operating under the MP scheme have reached a load of more than $85 \%$ of full capacity, and their total capacity was $24.8 \%$ of the total capacity of the biogas plants operating under the MP scheme. Fifteen out of 49 biogas plants (29.6\% of the total) have reduced their electricity generation (because of change of inputs, problems with thermal energy sales etc.) below $30 \%$ of full capacity, and their total capacity was $40.2 \%$ of the total capacity of the biogas plants operating under the MP scheme. The 15 biogas plants have sold less than $30 \%$ of their electricity under the MP scheme and they are located at municipal landfills. If the biogas plants operating at landfills exit the MP scheme, the population could expect an increase in waste management tariffs, as the Public Utilities Commission had so far reduced the waste management tariffs by the size of the mandatory procurement component.

Table 2. Loads of biogas cogeneration plants operating under the mandatory procurement scheme in 6 months of 2021

\begin{tabular}{|l|c|c|}
\hline Biogas plants, number & Indicator & \% of total \\
\hline $\begin{array}{l}\text { Total capacity of biogas plants operating under the MP scheme, MW } \\
\text { cumber of biogas plants operating under the MP scheme at a load of over 85\% of full }\end{array}$ & 14 & 28.75 \\
\hline $\begin{array}{l}\text { Total capacity of biogas plants operating under the MP scheme at a load of over 85\% of } \\
\text { full capacity, MW }\end{array}$ & 14.10 & 24.8 \\
\hline $\begin{array}{l}\text { Number of biogas plants operating under the MP scheme at a load of below 30\% of full } \\
\text { capacity }\end{array}$ & 15 & 30.6 \\
\hline $\begin{array}{l}\text { Total capacity of biogas plants operating under the MP scheme at a load of 30\% of full } \\
\text { capacity, MW }\end{array}$ & 22.8 & 40.2 \\
\hline
\end{tabular}

Source: authors' calculations based on the Latvian Biogas Association, 2021

In the 6 months of 2021, 3448.07 GWh of electricity was generated in Latvia, of which 125.36 GWh or $3.6 \%$ of the total was produced by biogas cogeneration plants under the mandatory procurement scheme, which was 2 percentage points less than on average in 2020 and only $41 \%$ of the output of electricity generated in 2020. (JSC "High Voltage..., 2021) If 
the proportion of electricity generated by biogas plants does not increase significantly in the second half of 2021 and electricity prices on the electricity exchange continue rising, a significant decrease in the amount of electricity sold under the mandatory procurement scheme by biogas plants could be expected by at least $20 \%$ in 2021 compared with 2020 .

Besides, there were 6 fewer biogas plants operating under the mandatory procurement scheme in the first half of 2021 than in 2020 in Latvia. In addition, the largest decrease in the number of biogas plants (3) occurred in the category with an installed capacity of 0.5-1.0 MW, while in the other categories the number of plants decreased by one, except for the largest biogas plants. As shown in Table 3, in the first half of 2021 the biogas plants with an installed capacity of 1.01.5 MW sold relatively the most electricity $-83 \%$ of the amount sold in 2020 . However, the largest difference was observed for the largest biogas plants - they sold only $23 \%$ of the level achieved in 2020, which also determined the total decrease in the average amount of electricity purchased under the MP scheme per plant. The total amount of electricity purchased in the first half of 2021 was only $40 \%$ of what was achieved in 2020, although the output of electricity was 1 percentage point higher, as the average price under the MP scheme decreased by EUR 0.01 per $\mathrm{kWh}^{-1}$. In the first half of 2021 , however, support above the market price was only $34 \%$ of the 2020 level. A significant decrease in support above the market price was reported for the category of the largest biogas plants - only $16 \%$ - and for the biogas plants with a capacity of 1.5-2.0 MW - only $27 \%$ of the respective level of 2020. Overall it could be concluded that the performance of biogas plants was significantly lower in the first half of 2021 than in 2020.

Table 3. Performance of biogas cogeneration plants operating under the mandatory procurement scheme in 6 months of 2021

\begin{tabular}{|c|c|c|c|c|c|c|c|c|c|c|c|c|}
\hline \multirow[t]{2}{*}{$\begin{array}{c}\text { Installed } \\
\text { capacity, } \\
\text { MWe }\end{array}$} & \multicolumn{2}{|c|}{ Biogas plants } & \multicolumn{3}{|c|}{$\begin{array}{l}\text { Purchased under MP } \\
\text { scheme, GWh }\end{array}$} & \multicolumn{3}{|c|}{$\begin{array}{c}\text { Purchased under MP } \\
\text { scheme, VAT excluded, } \\
\text { mln. EUR }\end{array}$} & \multirow{2}{*}{$\begin{array}{c}\text { Avg. } \\
\text { price } \\
\text { EUR } \\
\mathrm{kWh}^{-1 *}\end{array}$} & \multicolumn{3}{|c|}{$\begin{array}{l}\text { Support above market } \\
\text { price, mln. EUR }\end{array}$} \\
\hline & Number & $\begin{array}{l}\% \text { of } \\
\text { total }\end{array}$ & Total & $\begin{array}{l}\% \text { of } \\
\text { total }\end{array}$ & $\begin{array}{l}\text { Avg. per } \\
\text { plant }\end{array}$ & Total & $\begin{array}{l}\% \text { of } \\
\text { total }\end{array}$ & $\begin{array}{l}\text { Avg. } \\
\text { per } \\
\text { plant }\end{array}$ & & Total & $\%$ of total & $\begin{array}{l}\text { Avg. } \\
\text { per } \\
\text { plant }\end{array}$ \\
\hline$<0.5$ & 6 & 13.1 & 3.79 & 3.02 & 0.63 & 0.65 & 3.08 & 0.10 & 0.17 & 0.45 & 3.11 & 0.075 \\
\hline $0.5-1.0$ & 23 & 50.0 & 50.77 & 40.5 & 2.20 & 9.19 & 43.61 & 0.40 & 0.17 & 6.47 & 44.77 & 0.28 \\
\hline $1.0-1.5$ & 5 & 10.8 & 24.17 & 19.3 & 4.83 & 4.01 & 19.05 & 0.80 & 0.16 & 2.76 & 19.12 & 0.55 \\
\hline $1.5-2.0$ & 10 & 21.7 & 39.47 & 31.47 & 3.94 & 6.38 & 30.28 & 0.64 & 0.17 & 4.29 & 29.68 & 0.43 \\
\hline $2.0-6.5$ & 2 & 4.4 & 7.16 & 5.71 & 3.58 & 0.84 & 3.98 & 0.42 & 0.14 & 0.48 & 3.32 & 0.24 \\
\hline Total & 46 & 100.0 & 125.36 & 100.0 & 2.72 & 21.07 & 100.0 & 0.46 & 0.16 & 14.45 & 100.0 & 0.31 \\
\hline
\end{tabular}

Source: authors' calculations based on the Ministry of Economics, 2021; State Construction Control Bureau, 2021

There are several possible reasons for the decrease in the output of electricity produced by biogas plants in 2021:

1.On 2 September 2020, Cabinet Regulation No. 561 "Regulations regarding Electricity Generation in Cogeneration Mode, Supervision and Price Setting" entered into force, replacing Cabinet Regulation No. 262 of 16 March 2010 "Regulations regarding Electricity Generation by Using Renewable Energy Sources and Price Setting Procedures", which set a new requirement for the efficiency of cogeneration - a ratio of generated electricity to useful thermal energy. Therefore, some biogas plants cannot meet the requirement, as the efficiency of a biogas cogeneration plant is calculated based on the ratio of generated electricity to useful thermal energy, which is a prerequisite for steady revenues from the MP scheme. Due to the efficiency requirement, some of the biogas plants might have preferred to reduce the output of electricity in order to achieve the efficient use of thermal energy.

2.The feed-in tariff for several biogas plants operating under the MP scheme has been reduced since 2021, which might also be the reason for the decrease in the amount of electricity sold.

3. Some of the biogas plants might use their biogas produced as fuel for running boilers rather than for cogeneration facilities.

4.There are biogas plants that use their electricity generated for own consumption. The electricity generated by such biogas plants is therefore not included in the total domestic output of electricity.

5.If the biogas plants operating at landfills exit the MP scheme, the population could expect an increase in waste management tariffs, as the Public Utilities Commission had so far reduced the waste management tariffs by the size of the mandatory procurement component.

\section{CONCLUSIONS}

1. Since 2017 when the largest output of electricity was reported in Latvia (7.35 TWh), the output has continued decreasing every year. In the period 2016-2020, a decrease in the total output of electricity from the base year was $11.2 \%$ or $0.72 \mathrm{TWh}$, while a decrease in 2020 compared with 2017 was $25 \%$ or $1.84 \mathrm{TWh}$. In the same period, the total output of electricity from renewable sources decreased by $15 \%$ or $0.22 \mathrm{TWh}$, while a decrease in the output of electricity produced by biogas plants was $20.5 \%$ or $0.08 \mathrm{TWh}$. In the period 2016-2020, the average proportion of electricity produced by biogas plants in the total electricity output was $5.36 \%$.

2. In 2021, 46 biogas plants sold electricity under the mandatory procurement scheme, which was 6 plants fewer than in 2020 when the total amount of electricity sold by biogas plants under the MP scheme was $305.61 \mathrm{GWh}$, of which $40 \%$ by plants with a capacity of $0.5-1.0 \mathrm{MW}, 37 \%$ by plants with a capacity of $1.5-2.0 \mathrm{MW}$, and $10 \%$ by plants with a capacity of 2.0-6.5 MW. The electricity price under the mandatory procurement scheme for the producers of electricity

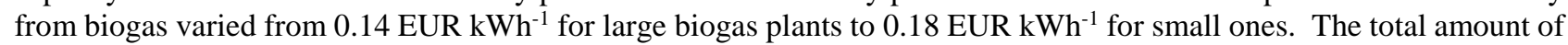


electricity purchased from biogas plants was EUR $52.87 \mathrm{mln}$., of which support above the market price amounted to EUR $41.90 \mathrm{mln}$. or $79 \%$.

3. In the first half of 2021 , biogas cogeneration plants operating under the mandatory procurement scheme contributed to $3.6 \%$ of the total output of electricity, which was 2 percentage points less than on average in 2020 . In the first half of 2021, all the analysed performance indicators of biogas plants were lower and significantly lagged behind those in 2020, which was a result of significant amendments made to the legal framework at the end of 2020 regarding the efficiency of cogeneration plants. Consequently, the biogas plants diversified their operations or stopped production, and it could be expected that in 2021 the amount of electricity sold under the mandatory procurement scheme would decrease by at least $20 \%$.

Acknowledgement. The research was promoted with the support of project lzp-2020/2-0413 "Assessment of the Implementation of the Latvian Bioeconomy Strategy 2030 and Possible Solutions for Achieving the Goals Set (LIBRA-LV)".

\section{REFERENCES}

1. Cesu beer, 2021, reduction of our CO2 footprint. Available in: https://www.cesualus.lv/en/betterfuture/we-reduce-our-co2footprint/ (accessed on 15/09/2021)

2. Cross-Sectoral Coordination Centre of the Republic of Latvia, 2014. National Development Plan of Latvia for 2014-2020.

3. Cross-Sectoral Coordination Centre of the Republic of Latvia, 2020. National Development Plan of Latvia for 2021-2027.

4. Enefit, 2020, energy market review, December 2020. Available in: https://www.enefit.lv/majai/zinas/Energijas-tirgus-apskats2020-gada-decembris (accessed on 15/09/2021)

5. European Commission, 2019, Climate neutral 2050. Available in: https://ec.europa.eu/clima/policies/strategies/2050_en (accessed on 1/09/2021)

6. European Commission, 2019, The European green deal. Available in: https://eurlex.europa.eu/resource.html?uri=cellar:b828d165-1c22-11ea-8c1f-01aa75ed71a1.0002.02/DOC_1\&format=PDF (accessed on 22/08/2021)

7. International Energy Agency, 2020. Available in: https://www.iea.org/reports/outlook-for-biogas-and-biomethane-prospects-fororganic-growth (accessed on 25/08/2021)

8. JSC "High Voltage Network", 2020, statistical data about electricity consumption. Available in: https://www.ast.lv/lv/electricitymarket-review?year=2020\&month=13 (accessed on 05/09/2021)

9. JSC "High Voltage Network", 2020, statistical data about electricity production by sources. Available in: https://www.ast.lv/lv/electricity-market-review?year=2020\&month=13 (accessed on 12/09/2021)

10. JSC "High Voltage Network", 2021, statistical data about electricity production by sources. Available in: https://www.ast.lv/lv/electricity-market-review?year=2021\&month=6 (accessed on 24/09/2021)

11. Latvian Biogas Association, 2021, internal members report on current events in the industry

12. Gustafsson M., S. Anderberg, 2021, Dimensions and characteristics of biogas policies - Modelling the European policy landscape. Renewable and Sustainable Energy Reviews, Vol. 135, ID110200. https://doi.org/10.1016/j.rser.2020.110200

13. Ministry of Agriculture, 2017, Latvian bioeconomy strategy 2030. Available in: https://www.llu.lv/sites/default/files/201807/Bioeconomy_Strategy_Latvia_LV.pdf (accessed on 22/08/2021)

14. Ministry of Economics of the Republic of Latvia, 2021, list of electricity producers. Available in: https://www.em.gov.lv/lv/elektroenergijas-razosana (accessed on 15/09/2021)

15. Ministry of Economics of the Republic of Latvia, 2021, production of electricity. Available in: https://www.em.gov.lv/lv/elektroenergijas-razosana (accessed on 10/09/2021)

16. Ministry of Economics of the Republic of Latvia, 2021, support for electricity producers. Available in: https://www.em.gov.lv/lv/atbalsts-elektroenergijas-razotajiem (accessed on 15/09/2021)

17. Czubaszek R., Wysocka-Czubaszek A., Banaszuk P. 2020, GHG Emissions and Efficiency of Energy Generation through Anaerobic Fermentation of Wetland Biomass, Energies, Vol. 13(24), 6497. https://doi.org/10.3390/en13246497

18. Bakkaloglu S., Lowry D., Fisher R. E., France J. L., Brunner D., Chen H., Nisbet E. G. 2021. Quantification of methane emissions from UK biogas plants. Waste Management, Vol. 124, pp. 82-93. https://doi.org/10.1016/j.wasman.2021.01.011

19. State Construction Control Bureau of Latvia, 2021. Amounts paid to merchants in 2020 within the OI. Available in: https://www.bvkb.gov.lv/lv/elektroenergijas-obligata-iepirkuma-mehanisma-uzraudziba-un-kontrole (accessed on 15/09/2021)

20. State Construction Control Bureau of Latvia, 2021, mandatory-procurement-mechanism-monitoring. Available in: https://www.bvkb.gov.lv/lv/elektroenergijas-obligata-iepirkuma-mehanisma-uzraudziba-un-kontrole (accessed on 12/09/2021)

21. Zhu T., Curtis J., Clancy M. 2019. Promoting agricultural biogas and biomethane production: Lessons from cross-country studies. Renewable and Sustainable Energy Reviews, Vol. 114, ID 109332. https://doi.org/10.1016/j.jclepro.2020.125065

22. Brémond U., Bertrandias A., Philippe J., Nicolas S., Carrere B.H. 2020. A vision of European biogas sector development towards 2030: Trends and challenges. Journal of Cleaner Production, Vol. 287, ID 125065. https://doi.org/10.1016/j.jclepro.2020.125065 